\title{
Autologous hematopoietic cell transplan- tation for HIV-related lymphoma: results of a single center (CIC725) matched case-control study
}

Marina O. Popova, Yulia A. Rogacheva, Anastasia V. Nekrasova, Ivan V. Tsygankov, Ali Basahel, Kirill V. Lepik, Olga V. Pirogova, Elena I. Darskaya, Lilia V. Stelmakh, Yurii R. Zalyalov, Ivan S. Moiseev, Sergey N. Bondarenko, Natalia B. Mikhailova, Boris V. Afanasyev

R. Gorbacheva Memorial Research Institute of Children Oncology, Hematology and Transplantation, Chair of Hematology, Transfusiology and Transplantation, The St. Petersburg First State Medical I. Pavlov University (CIC725)

Dr. Marina O. Popova, R. Gorbacheva Memorial Research Institute of Children Oncology, Hematology and Transplantation, The St. Petersburg First State I. Pavlov Medical University, L. Tolstoy St. 6-8, 197022, St. Petersburg, Russian Federation
Phone: +7 (911) 7113977

Email: marina.popova.spb@gmail.com

\section{Summary}

Human immunodeficiency virus (HIV) infection is associated with an increased incidence of non-Hodgkin lymphoma (NHL) and Hodgkin lymphoma (HL). Throughout the HAART era, autologous stem cell transplantation (ASCT) has been reported as a feasible, safe, and useful approach to either rescue or consolidate HIV-related lymphoma patients. However, the number of published comparative studies according to the HIV status is limited. The aim of the study was to estimate the early safety and efficacy of high-dose chemotherapy followed by autologous hematopoietic cell transplantation in HIV-related lymphoma. Since the Jan 2016 seven patients with HIV-related lymphoma who have undergone ASCT were included in the prospective singe centre study (study group - HIV group, $\mathrm{n}=7$ ). The data of the non-HIV-infected patients with lymphoma who have undergone ASCT at the same period of time (control group, $n=28$ ) were collected to compare the efficacy and safety of the procedure (ratio 1:4). Median follow up time was 12 (1-20) months in study group and 8 (1-20) months in control group. The primary endpoint was overall survival (OS) at 12 months after ASCT. Secondary end points were hematopoietic recovery and organ toxicity, progression free survival (PFS) and relapse rate at 12 months after ASCT. Here we report the early results of a single institution (EBMT center CIC725) matched case-control study. This was an observation trial designed to prospectively evaluate the safety and effectiveness of ASCT for patients with HIV-related lymphoma.

One-year overall survival in patients with HIV-related lymphoma was $100 \%$, the probability of PFS $-85,7 \%$, relapse rate $-14,3 \%$ and did not differ from the control group. There were not found statistical significant differences between two groups in hematopoietic recovery and toxicity rate. Preliminary data provide further evidence that HIV status does not affect the outcome of ASCT for lymphoma, and therefore HIV status alone should no longer exclude these patients from transplant clinical trials.

\section{Keywords}

Autologous hematopoietic cell transplantation, HIV, HIV-related lymphoma, high-dose chemotherapy, non-Hodgkin lymphoma, Hodgkin lymphoma, matched case-control study. 


\section{Introduction}

Infection with human immunodeficiency virus (HIV) is associated with a significantly increased risk of cancer, including Hodgkin lymphoma (HL) and non-Hodgkin lymphoma (NHL) even when patients are treated successfully with contemporary antiretroviral therapy $[1,2]$. AIDS related malignancies remain a leading cause of mortality [3]. Before the introduction of highly active anti-retroviral therapy (HAART), HIV-infected patients were not candidates for standard, combination chemotherapeutic regimens because of the significant risk of opportunistic infection and poor malignancy response rates [4]. Therapy outcome in patients with HIV-related malignancies have improved since the improvement of HAART availability [5-8]. In the HAART era, treatment of HIV-related lymphomas with standard doses of chemotherapy became possible for HIV positive patients [9-14].

The role of autologous hematopoietic stem cell transplantation (ASCT) in the care of patients with HIV-related lymphoma, however, remains unclear. In the non-HIV setting, patients with relapsed refractory NHL and HL have benefits from treatment with high-dose chemotherapy and ASCT $[15,16]$. Early pivotal studies come from Europe and the United States demonstrated safety and efficacy the use of ASCT in the care of patients with high-risk, relapsed refractory HIV-related lymphoma $[17,18]$. These initial experiences were encouraging and spurred other investigators to study the use of ASCT for patients with lymphoma and HIV. The summary of the studies of high-dose chemotherapy followed by autologous hematopoietic cell transplantation in HIV-related lymphoma adapted from the Serrano et al. [19] is outlined in Table 1. The limitation of these studies is their retrospective nature with a large variety in patient population, status of the disease, conditioning regimen and HAART strategy. That is why the role of high-dose chemotherapy followed by ASCT in lymphoma patients with HIV is still a subject of controversy.

There is an urgent need for prospective comparative matched case-controlled studies to prove the safety and efficacy of ASCT in HIV-related lymphoma and their number is limited. There are three studies have been published that in one way or another meet the criteria prospective, comparative, matched case-controlled studies [26, 27, 28].

Here we report the early results of a single institution, EBMT center CIC725, matched case-control study. This was an observational trial designed to prospectively evaluate the safety and effectiveness of ASCT for patients with HIV-related lymphoma.

\section{Patients and methods}

\section{Study design}

Between January 2016 and October 2017, an observational study was conducted at Raisa Gorbacheva Memorial Research Institute of Children Oncology, Hematology and Transplantation, The First State I. Pavlov Medical University of St. Petersburg (CIC725). Seven patients with HIV-related
NHL or HL were enrolled in a trial. An approval for the trial was issued by the University Institutional Review Board. All the patients signed an approved informed consent, in accordance with the Declaration of Helsinki. The data on twenty-eight non-HIV-infected lymphoma patients who underwent ASCT at the same time period (control group, $\mathrm{n}=28$ ) were also collected to compare the efficacy and safety of the procedure (1:4). The patients were matched for age at ASCT, disease status at ASCT, number of prior regimens of chemotherapy, time from lymphoma diagnosis to ASCT, conditioning regimen and tumor histology.

\section{Eligibility criteria}

The indications for ASCT included NHL or HL if they met standard transplant criteria. HIV positive patients were required to exhibit a viral load of $<50,000$ copies $/ \mathrm{ml}$, being free of overt opportunistic infections at the time of ASCT, and receiving HAART for more than 6 months.

\section{Stem cell mobilization and conditioning regimen}

For stem cell mobilization, the patients received cyclophosphamide (CY) at $4000 \mathrm{mg} / \mathrm{m}^{2}$ with hydration, and Mesna (15 mg/kg) before and 3, 6, and 9 hours after CY for uroprotection, or an alternative salvage chemotherapy to which the lymphoma was responding. Granulocyte colonystimulating factor (G-CSF) was administered at a dose of $10 \mu \mathrm{g} / \mathrm{kg} /$ day starting 2 days after the chemotherapy. Leukapheresis was performed since the white blood count (WBC) reached $\geq 0.5 \times 10^{9} / \mathrm{L}$, a maximum of 3 harvests, until an intended number of $2 \times 10^{6} \mathrm{CD} 34+$ cells $/ \mathrm{kg}$ has been collected. In cases of poor stem cell mobilization (failed leukapheresis), bone marrow (BM) served as a source of hematopoietic stem cells (HSC) using a standard surgical procedure. Patients who met trial eligibility criteria underwent ASCT following a preparative regimen that consisted of modified BEAM to BeEAM treatment where the carmustine $300 \mathrm{mg} / \mathrm{m}^{2}$ (day -6) was replaced by Bendamustine $160 \mathrm{mg} /$ $\mathrm{m}^{2} /$ day at day -7 , day -6 . Etoposide $100 \mathrm{mg} / \mathrm{m}^{2}$ daily (days -5 to -2 ), cytarabine $200 \mathrm{mg} / \mathrm{m}^{2}$ twice daily (days -5 to -2 ), and melphalan $140 \mathrm{mg} / \mathrm{m}^{2}$ (day -1) [29]. Patients underwent ASCT on day 0 and received growth factor, transfusion, and antimicrobial supportive care as per the respective institutional standards.

Autologous peripheral stem cells were thawed in a $37^{\circ} \mathrm{C}$ water bath and infused through the patient's central venous catheter on transplantation day 0 .

\section{Clinical endpoints}

This study was designed to assess the safety and tolerability of intensive chemotherapy and ASCT for the treatment of HIV-related NHL and HL. The primary end point for the trial was one-year OS after ASCT. The secondary endpoints were as follows: hematopoietic recovery and organ toxicity, transplant-related mortality (TRM), progression free survival (PFS), the cumulative incidence of relapse/progressionat 12 months after ASCT.

The patients underwent daily routine post-transplant blood tests from day 0 through the period of neutrophil recovery, and as per the respective institutional standards. The time 
Table 1. Summary of reported studies autologous HSCT for non-Hodgkin's and Hodgkin's lymphoma in HIV-infected patients

\begin{tabular}{|c|c|c|c|c|c|c|c|}
\hline & $\begin{array}{l}\text { Krishnan } \\
\text { et al. [20], } \\
2005\end{array}$ & $\begin{array}{l}\text { Spitzer } \\
\text { et al. [21], } \\
2008\end{array}$ & $\begin{array}{l}\text { Balsalobre } \\
\text { et al. [22], } \\
2009\end{array}$ & $\begin{array}{l}\text { Serrano } \\
\text { et al. [23], } \\
2010\end{array}$ & $\begin{array}{l}\text { Re et al. } \\
\text { [24], } \\
2009\end{array}$ & $\begin{array}{l}\text { Gabarre } \\
\text { et al. [25], } \\
2004\end{array}$ & $\begin{array}{l}\text { Alvarnas } \\
\text { et al. [26], } \\
2016\end{array}$ \\
\hline Patients, total n & 20 & 20 & 68 & 33 & 27 & 14 & 40 \\
\hline $\begin{array}{l}\text { Non-Hodgkin's } \\
\text { lymphoma }\end{array}$ & 18 & 15 & 50 & 23 & 19 & 8 & 25 \\
\hline Hodgkin's lymphoma & 2 & 5 & 18 & 10 & 8 & 6 & 15 \\
\hline $\begin{array}{l}\text { Disease Status at } \\
\text { ASCT, Relapse/ } \\
\text { Refractory }\end{array}$ & 0 & 0 & 8 & 0 & 0 & 3 & 1 \\
\hline $\begin{array}{l}\text { CD34+ cells collected } \\
\left(\times 10^{6} / \mathrm{kg}\right) \text {, median }\end{array}$ & 10.60 & 4.62 & 4.50 & 3.30 & 5.90 & 5.80 & 3.90 \\
\hline $\begin{array}{l}\text { Days to neutrophil } \\
\text { engraftment, median }\end{array}$ & 10 & 11 & 11 & 12 & 10 & 12 & 28 \\
\hline $\begin{array}{l}\text { Days to platelet } \\
\text { engraftment, median }\end{array}$ & NR & 13 & 14 & 20 & 12 & 11 & 18 \\
\hline $\begin{array}{l}\text { HAART interruptions } \\
\text { during } \mathrm{HSCT}, \%\end{array}$ & 55 & NR & 23 & 39 & 23 & 7 & 32 \\
\hline $\begin{array}{l}\text { Median follow-up } \\
\text { time, months }\end{array}$ & 32 & 6 & 32 & 61 & 44 & 36 & 24.8 \\
\hline $\begin{array}{l}\text { Non-relapse-related } \\
\text { mortality at } 1^{\text {st }} \text { year, \% }\end{array}$ & 5 & 5 & 7,5 & 15 & 0 & 0 & 5.2 \\
\hline $\begin{array}{l}\text { Relapse of lymphoma } \\
\text { after HSCT, \% }\end{array}$ & 10 & 45 & 29 & 21 & 22 & 57 & 12.5 \\
\hline $\begin{array}{l}\text { Event-free } \\
\text { survival, \% } \\
\end{array}$ & 85 & 49.5 & 56.5 & 53 & 75 & 20 & NR \\
\hline Overall survival, \% & 85 & 74 & 61 & 61 & 75 & 30 & 82 \\
\hline $\begin{array}{l}\text { CD4+ cells, 6-12 } \\
\text { months after HSCT, } \\
\text { median (range) }\end{array}$ & $\begin{array}{l}175 \\
(25-1064)\end{array}$ & $\begin{array}{l}207 \\
(53-574)\end{array}$ & $\begin{array}{l}163 \\
(8-1159)\end{array}$ & $\begin{array}{l}200 \\
(90-1346)\end{array}$ & $\begin{array}{l}190 \\
(88-545)\end{array}$ & $\begin{array}{l}209 \\
(22-530)\end{array}$ & $\begin{array}{l}280 \\
(29-1148)\end{array}$ \\
\hline
\end{tabular}

Note: HAART, highly active antiretroviral therapy; HSCT, hematopoietic stem cell transplant; NR, not records.

to hematopoietic recovery was defined as the first of day of $>500$ neutrophils $/ \mu \mathrm{L}$ following nadir and time to platelet count $>20,000 / \mu \mathrm{L}$ at the first of day with no platelet transfusions for 2 preceding days. Post-AHCT toxicities were graded using the Common Terminology Criteria for Adverse Events, version 4. Microbiologically documented infections were classified by clinical site, date of onset, and severity of the disease. The disease status was assessed in the patients before ASCT, at day +100 or earlier if signs of the disease re-appeared, and 1 year after ASCT. Responses of lymphoma to therapy were assessed using the Cheson criteria for determination of complete remission (CR), and $\mathrm{CR}+$ partial remission (PR) rates at day +100 [30]. The data of tests for HIV status (CD4+ cells, viral load) were collected from the HIV Department where the patients were assigned and observed.

\section{Statistical analysis}

Survival estimates were calculated based on the Kaplan-Meier method. Differences between survival curves were assessed by the log-rank test. Potential baseline differences between the two groups were examined using the Mann-Whitney test for continuous variables or Fisher's exact test for categorical variables. Patients who were alive at the time of analysis were censored at the last contact date. Overall survival was defined as the interval from day 0 ASCT to the death from any cause. Transplant-related mortality was defined as death occurring in a patient from causes other than relapse/progression. Progression free survival was defined as the interval from day 0 ASCT to death, disease relapse, or progression. The cumulative incidence of relapse/progressionwas defined as relapse or progressionoccurring in a patient the interval from day 0 ASCT to 12 months. 


\section{Results}

\section{Patient characteristics}

A consecutive case-series of 7 HIV-group patients and 28 matched control group treated with ASCT between January 2016 and October 2017 were included. Patient, disease, and treatment characteristics for both groups are provided in Table 2. Both groups were comparable for all clinical and transplantation characteristics except for the higher proportion of male sex $(\mathrm{p}=0.03)$ in HIV-group, misbalance in type of lymphoma: presence of non-Hodgkin T-cell lymphoma and prevalence of Hodgkin lymphoma in control group.

Table 2. Patients under study, clinical features, and treatment characteristics

\begin{tabular}{|c|c|c|c|}
\hline \multirow[t]{2}{*}{ Clinical and laboratory parameters } & $\begin{array}{l}\text { HIV group } \\
\text { cohort }\end{array}$ & Control group cohort & $P$ values \\
\hline & $\mathrm{n}$ & $\mathrm{n}$ & \\
\hline Patients & 7 & 28 & \\
\hline Median age, years range & $41(32-59)$ & $31(19-59)$ & NS \\
\hline Male sex & 7 & 16 & 0.03 \\
\hline Non-Hodgkin lymphoma & 3 & 8 & 0.46 \\
\hline Diffuse large B-cell/plasmablastic & 2 & 4 & \\
\hline Burkitt/Burkitt-like & 1 & 1 & \\
\hline Peripheral T-cell & 0 & 3 & \\
\hline Hodgkin lymphoma & 4 & 20 & 0.46 \\
\hline Mixed cellularity & 1 & 2 & \\
\hline Nodular sclerosis & 3 & 18 & \\
\hline \multicolumn{4}{|l|}{ Stage at diagnosis } \\
\hline II & 2 & 9 & 0.85 \\
\hline III & 2 & 7 & 0.84 \\
\hline IV & 3 & 4 & 0.09 \\
\hline Bone marrow involvement & 1 & 2 & 0.54 \\
\hline \multicolumn{4}{|l|}{ Treatment before ASCT } \\
\hline Median no. of treatment lines (range) & $3(2-6)$ & $3(1-5)$ & NS \\
\hline Patients undergoing rituximab treatment & 2 & 4 & 0.36 \\
\hline Radiotherapy & 2 & 11 & 0.59 \\
\hline \multicolumn{4}{|l|}{ Disease status at ASCT } \\
\hline CR/PR & 7 & 25 & 0.36 \\
\hline Relapse & 0 & 3 & 0.36 \\
\hline \multicolumn{4}{|l|}{ ASCT conditioning regimen } \\
\hline BeEAM & 6 & 15 & 0.12 \\
\hline BeEAM/variants & 0 & 10 & 0.06 \\
\hline BeEAM+Rituximab & 1 & 3 & 0.78 \\
\hline Median CD34+ infused cells 10^6/kg (range) & $3,4(2,6-6,0)$ & $3,5(1,7-6,87)$ & NS \\
\hline Time from diagnosis to ASCT (months) & $17(9-113)$ & $17,5(8-67)$ & NS \\
\hline Median months of follow-up from ASCT (range) & $12(1-20)$ & $8(1-20)$ & NS \\
\hline
\end{tabular}

ASCT, autologous stem cell transplantation; NHL, non-Hodgkin lymphoma; CP, complete remission; PR, partial remission; NS, non-significant diference. 
One patient was diagnosed with HIV infection concomitant with the lymphoma diagnosis and started on antiretroviral therapy together with chemo. Meanwhile, six patients in HIV group had a long history of HIV infection before the lymphoma was diagnosed. Median time from the registration of HIV-positive status to lymphoma diagnosis was 1734 days (57.8 months). HIV status in study group at the moment of transplantation was as follows: HIV viral load was undetectable (100\%); the median number of CD4+ cells was 265 cells/mcl; all the subjects received HAART. Neither patient had any planned or needed interruptions in their HAART during ASCT. All individual patient and HAART regimen have been consulted with the HIV specialist and changed the regimen before ASCT taking into account drug-drug interactions. Only in two patients before ASCT the modification of the scheme HAART was required.

Six patients in HIV group received peripheral blood stem cell grafts, and BM was transfused in one case. The median transplanted HSC dose was $3.9 \times 10^{6} \mathrm{CD} 34+$ cells $/ \mathrm{kg}$ (range, 1.6-11.0). A median of 2 apheresis collections was performed (range, 1-3). A median of $3.4 \times 10^{6} \mathrm{CD} 34+$ cells $/ \mathrm{kg}$ (range, $2.6-6.0 \times 10^{6} / \mathrm{kg}$ ) was transfused to the patients.

1a

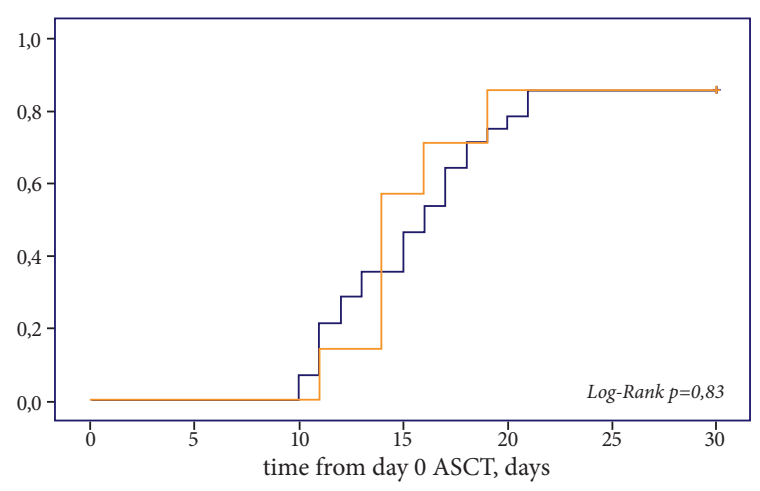

\section{Engraftment}

The median time to achievement of an absolute neutrophil count (ANC) of $\geq 0.5 \times 10^{9} / \mathrm{L}$ was similar for both groups: 14 days (range, 11-30 days) in HIV-infected group and 16 days (range, 10-30 days) in control group (Fig. 1a). The median time to achievement of an unsupported platelet count of $\geq 20 \times 10^{9} / \mathrm{L}$ was 15 days (range, 11-30 days) in HIV-infected group and 14 days (range, 11-30 days) in control group (Fig. 1b).

\section{Toxicities}

No fatal regimen-related toxicity occurred. Neither patient developed grade III or IV nausea or vomiting. Three patients developed oropharyngeal mucositis (3 cases - grade I-II, no one grade III). Tree patients experienced febrile neutropenia. Tree patients had a documented bacteremia within 100 days post-ASCT (1 coagulase-negative staphylococcus, 2 Klebsiella pneumoniae). Comparative characteristics of non-hematologic toxicities ( $\leq 100$ days post-ASCT) are listed in Table 3.

Figure 1. Time to hematopoietic recovery for neutrophils (1a), and platelets (1b) from day 0 of ASCT in HIV group versus control patients

Table 3. Comparative characteristics of non-hematologic toxicities in the patients

\begin{tabular}{|l|l|l|l|l|l|}
\hline Feature & \multicolumn{4}{|l|}{ HIV-infected group $(\mathbf{n}=7)$} & \multicolumn{2}{l|}{ Control group $(\mathbf{n}=28)$} & P value \\
\hline CTCAE Toxicities & $\mathrm{n}(\%)$ & Grade max & $\mathrm{n}(\%)$ & Grade max & $\mathbf{p}=$ \\
\hline \multicolumn{1}{|c|}{ enteropathy } & $3(42,8)$ & 3 & $7(25)$ & 3 & 0,875 \\
\hline \multicolumn{1}{|c|}{ nephrotoxicity } & $1(14,2)$ & 3 & $3(10,7)$ & 1 & 101 \\
\hline hepatotoxicity & $4(57)$ & 4 & $10(35,7)$ & 2 & 1.01 \\
\hline mucositis & $3(42,8)$ & 2 & $10(35,7)$ & 3 & 0.12 \\
\hline Stomatitis/pharyngitis & $3(42,8)$ & 2 & $8(28,5)$ & 3 & 0.46 \\
\hline Febrile neutropenia & $3(42,8)$ & - & $15(53,6)$ & - & 0.61 \\
\hline Documented infection & $3(42,8)$ & - & $10(35,7)$ & - & 0.72 \\
\hline Metabolic & $7(100)$ & 2 & $20(71,4)$ & 2 & 0.10 \\
\hline Headache/other pain & $3(42,8)$ & 2 & $7(25)$ & 3 & 0.10 \\
\hline
\end{tabular}




\section{Outcomes}

With a median follow-up of 12 months (range, 1.2-20.7 months) in HIV group and 8 (1-20) months in control group, 2 patients died in control group; one of them died within 1 year of transplant. Relapse of the underlying disease was a cause of death in both cases. There were no registered events classified as transplant-related mortality. The overall one-year survival $(n=35)$ was $97.1 \%$. Overall survival at 1 year was $100 \%$ in HIV group, $96.4 \%$ - control group, and were not significantly different between the groups (Fig. 2a).

At the time of transplant, 4 (57\%) patients in HIV group and $17(60.7 \%)$ patients in control group were in CR, three pa- tients $(42.8 \%)$ in HIV group and 8 (28.5\%) patients in control group were in $\mathrm{PR}$, whereas three $(10.7 \%)$ patient in control group had active diseaseat the moment of ASCT after achieving a PR to salvage therapy. During the first year after ASCT, 1 (3.6\%) patient in control group had relapse of the disease and died on day +73 and 1 patient (14.2\%) in HIV group with HL where the anticancer immunotherapy was initiated. The probability of 1-year PFS for all patients was $88.6 \%$, in HIV group $-85.7 \%$ and $89.3 \%$ for control group $(\mathrm{p}=0.98)$ (Fig. 2b). The cumulative incidence of relapse/progression at 1 year was $11.4 \%$. The cumulative incidence of relapse/progression was 14,3\% in HIV group and did not differ from the control group $10.7 \%(\mathrm{p}=0.98)$.

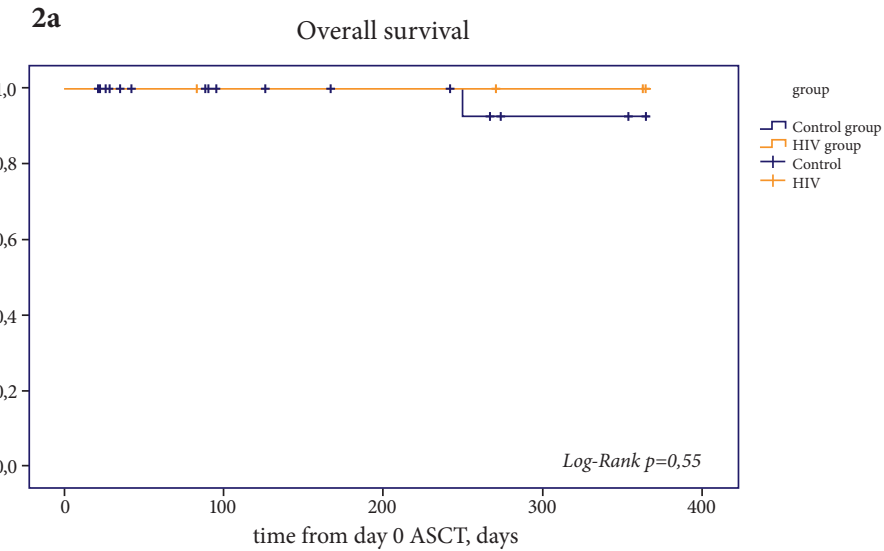

2b Progression free survival

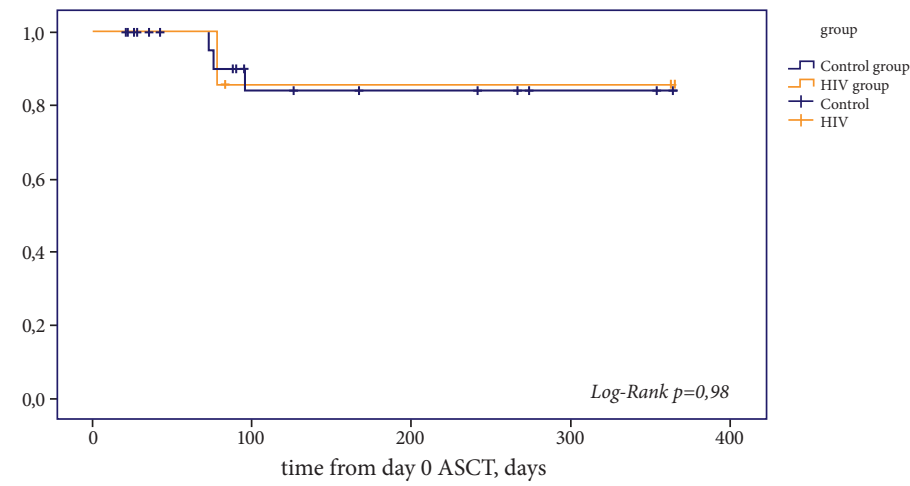

Figure 2. Overall survival (2a), and progression-free survival (2b) at the term of 1 year in HIV group versus control patients

\section{Discussion}

Wide application of effective anti-HIV therapy allowed patients with HIV-related lymphoma to benefit from standard chemotherapeutic regimens [9-14]. Clinical outcomes after treatment of these patients, including OS and PFS of treatment these patients similar comparable with those of nonHIV-infected individuals both in NHL and HL cases $[7,11$, $13,14,31]$.

In the early 90's clinical studies established ASCT as the standard of care for managing patients with chemotherapy-sensitive, relapsed/refractory NHL and HL [15-16, 32]. HIV infection historically has been considered as a contraindication to ASCT. With the improvement of supportive care, and the accumulation of experience in ASCT, as well as long-term results of the use of HAART there was an opportunity to extend implementation of high-dose chemotherapy followed by ASCT to HIV-infected patients. Series of the studies has been reported ASCT as a feasible, safe, and useful approach to either rescue or consolidate HIV-related lymphoma patients [19, 20-26].

Alvarnas JC et al. highlighted that published ASCT studies were largely limited to centers with significant HIV-related expertise. This has prevented full acceptance of ASCT as the standard of care for patients with relapsed and resistant HIV-related lymphoma [26]. We cannot disagree with the statement of Dr. Alvarnas. Our transplant activity confirms the fact that ASCT for patients with lymphoma and HIV remain largely limited to centers with significant HIV-specific expertise [33].

Today we need prospective comparative matched case-controlled studies in order to confirm safety and efficacy of ASCT in HIV-related lymphoma. Three studies that in one way or another meet these criteria were published. One study is a single-institution one, from the City of Hope - the United States center that pioneered the use of hematopoietic stem cell transplantation for HIV positive patients [27]. Two other comparative trials represent a registry-based studies from the EBMT and CIBMTR databases $[26,28]$. Table 4 presents a summary of trials with appropriate comparative analyses of HIV-infected patients and matched cohorts from non-HIV-infected patients who underwent ASCT for treatment of NHL and HL. The well-designed single center and multicenter studies have shown that HIV status does not affect the outcome of ASCT performed for NHL and HL. Such a conclusion is based on a total group of $122 \mathrm{HIV}$-infected individuals with lymphoma observed in the three studies.

This study and early-stage data confirm some previously published statements that high-dose chemotherapy with ASCT is a safe and effective procedure in patients with highrisk, relapsed refractory HIV-related lymphoma. The issues of ASCT safety in this category of patients become actual 
Table 4. Summary of trials with comparative analysis of HIV-infected patients versus matched cohort of non-HIV-infected patients who underwent ASCT for treatment of non-Hodgkin's and Hodgkin's lymphomas

\begin{tabular}{|c|c|c|c|c|c|c|}
\hline & \multicolumn{2}{|c|}{ Krishnan et al. [27], 2010} & \multicolumn{2}{|c|}{ Diez-Martin et al. [28], 2009} & \multicolumn{2}{|c|}{ Alvarnas et al. [26], 2016} \\
\hline \multirow[t]{2}{*}{ Study design } & \multicolumn{2}{|c|}{$\begin{array}{l}\text { A single institution, } \\
\text { retrospective, matched } \\
\text { case-control study }\end{array}$} & \multicolumn{2}{|c|}{$\begin{array}{l}\text { A registry-based, } \\
\text { retrospective, individual- } \\
\text { matched, case-controlled } \\
\text { study }\end{array}$} & \multicolumn{2}{|c|}{$\begin{array}{l}\text { A prospective phase } 2 \\
\text { multicenter trial (\#NCTO1141712), } \\
\text { comparison with CIBMTR } \\
\text { comparison data set }\end{array}$} \\
\hline & HIV & control & HIV & control & HIV & control \\
\hline Patients, total $\mathrm{n}$ & 29 & 29 & 53 & 53 & 40 & 151 \\
\hline Non-Hodgkin's lymphoma & 29 & 29 & 35 & 35 & 25 & - \\
\hline Hodgkin's lymphoma & 0 & 0 & 18 & 18 & 15 & - \\
\hline $\begin{array}{l}\text { Disease Status at ASCT, } \\
\text { Relapse or Refractory }\end{array}$ & 7 & 6 & 5 & 5 & 1 & - \\
\hline $\begin{array}{l}\text { ASCT Conditioning } \\
\text { Regimen, BEAM }\end{array}$ & 0 & 3 & 3 & 6 & 40 & - \\
\hline TBI based & 4 & 4 & 50 & 43 & 0 & - \\
\hline 0ther (*BCNU/VP16/CY) & $25^{*}$ & $22^{*}$ & 0 & 4 & 0 & - \\
\hline $\begin{array}{l}\text { Median follow-up time, } \\
\text { months }\end{array}$ & $\begin{array}{l}62.4 \\
(0.7-123.3) \\
\end{array}$ & $\begin{array}{l}48.4 \\
(4.4-101.6) \\
\end{array}$ & $30(3-81)$ & $29.5(3-98)$ & $24.8(2.8-27.7)$ & - \\
\hline $\begin{array}{l}\text { Days to neutrophil } \\
\text { engraftment }\end{array}$ & $10(5-19)$ & $11(9-35)$ & $11(8-36)$ & $11(7-19)$ & 28 & - \\
\hline \multirow{2}{*}{$\begin{array}{l}\text { Non-relapse-related } \\
\text { mortality at } \text { 1st }^{\text {st }} \text { year, } \%\end{array}$} & $11(4-28 \%)$ & $4(1-25)$ & - & - & $5.2(0.9-15.2)$ & - \\
\hline & \multicolumn{2}{|c|}{$p=0.18$} & \multicolumn{2}{|l|}{-} & \multicolumn{2}{|c|}{$p=0.9$} \\
\hline \multirow[t]{2}{*}{$\begin{array}{l}\text { Progression free survival } \\
\text { at } 1-2.5 \text { year, \% }\end{array}$} & 76 (62-85\%) & $56(45-66 \%)$ & 61 (47-75\%) & $56(41-71 \%)$ & $\begin{array}{l}82.4 \\
(66.6-91.2 \%)\end{array}$ & $\begin{array}{l}69.5 \\
(61.1-76.4 \%)\end{array}$ \\
\hline & \multicolumn{2}{|c|}{$\mathrm{p}=0.33$ (2 years) } & \multicolumn{2}{|c|}{$\mathrm{p}=\mathrm{NS}(2.5$ years $)$} & \multicolumn{2}{|c|}{$\mathrm{p}=0.06$ (1 year) } \\
\hline \multirow[t]{2}{*}{$\begin{array}{l}\text { 0verall survival } \\
\text { at } 1-2.5 \text { year, } \%\end{array}$} & 75 (61-85\%) & 75 (60-85\%) & 61.5 (47-76\%) & 70 (57-84\%) & $\begin{array}{l}87.3 \\
(72.1-94.5 \%)\end{array}$ & $\begin{array}{l}87.7 \\
(80.9-92.2 \%)\end{array}$ \\
\hline & \multicolumn{2}{|c|}{$\mathrm{p}=0.93$ (2 years) } & \multicolumn{2}{|c|}{$\mathrm{p}=\mathrm{NS}$ (2.5 years) } & \multicolumn{2}{|c|}{$\mathrm{p}=0.33$ (1 year) } \\
\hline
\end{tabular}

given that HSCT is a platform for development and application of gene therapy, both with classic and more advanced genome editing techniques aimed to eradicate HIV infection [34-37]. In the last few years with a development of the genome editing technology based on autologous hematopoietic stem cell transplantation is becoming one of the most promising methods of HIV one shot therapy procedure. Hematopoietic stem cells are one of the most popular and promising target for gene therapy protocols for the treatment of numerous disease and conditions, due to their tissue-specific homing, ability for differentiation and production of various blood cells, as well as broad clinical experience with their transplantation [38, 39].

There is no doubt that further research in this field and every new patient treated with ASCT procedure is of great value, and multicenter prospective comparative matched case-controlled studies are required. Our pilot study involved a modest number of patients observed for limited terms. However, it contributes to the solution of an urgent problem. Our preliminary data provide further evidence that HIV status does not affect the outcome of ASCT for lymphoma. Patients with HIV-related lymphoma should be considered candidates for ASCT if they meet standard transplant criteria.

\section{Acknowledgments}

The authors would like to acknowledge all medical staff at our University' BMT clinic CIC725. Special thanks to our transplant nurses for their particular care of our patients. Many thanks to the HIV specialists at the First Pavlov State Medical University of Saint-Petersburg, especially to Prof. Lioznov D. A., Chief of the Department, and to entire medical staff of St. Petersburg HIV Center for detailed clinical and laboratory data provided for the patients.

\section{Conflict of interest}

No conflict of interests is declared.

\section{References}

1. Cooksley CD, Hwang LY, Waller DK, Ford CE. HIV-related malignancies: community-based study using linkage of cancer registry and HIV registry data. Int J STD AIDS. 1999;10(12):795-802. 
2. Yanik EL, Napravnik S, Cole SR, Achenbach CJ, Gopal S, Olshan A, et al. Incidence and timing of cancer in HIV-infected individuals following initiation of combination antiretroviral therapy. Clin Infect Dis. 2013;57:756-764.

3. Bonnet F, Lewden C, May T, Heripret L, Jougla E, Bevilacqua S, Costagliola D, Salmon D, Chêne G, Morlat P. Malignancy-related causes of death in human immunodeficiency virus-infected patients in the era of highly active antiretroviral therapy. Cancer. 2004; 101; 317-324.

4. Kaplan LD, Straus DJ, Testa MA, Von Roenn J, Dezube BJ, Cooley TP, et al. Low-dose compared with standard-dose m-BACOD chemotherapy for non-Hodgkin's lymphoma associated with human immunodeficiency virus infection. National Institute of Allergy and Infectious Diseases AIDS Clinical Trials Group. N Engl J Med.1997; 336(23):16411648.

5. Gopal S, Patel MR, Yanik EL, Cole SR, Achenbach CJ, Napravnik S, et al. Temporal trends in presentation and survival for HIV-associated lymphoma in the antiretroviral therapy era. J Natl Cancer Inst. 2013;105(16):1221-1229.

6. Little RF, Pittaluga S, Grant N, Steinberg SM, Kavlick MF, Mitsuya H, Franchini G, Gutierrez M, Raffeld M, Jaffe ES, Shearer G, Yarchoan R, Wilson WH. Highly effective treatment of acquired immunodeficiency syndrome-related lymphoma with dose-adjusted EPOCH: impact of antiretroviral therapy suspension and tumor biology. Blood. 2003; 101(12):4653-4659.

7. Spina M, Gabarre J, Rossi G, Fasan M, Schiantarelli C, Nigra E, Mena M, Antinori A, Ammassari A., Talamini R, Vaccher E, di Gennaro G, Tirelli U. Stanford V regimen and concomitant HAART in 59 patients with Hodgkin disease and HIV infection. Blood. 2002;100(6):1984-1988.

8. Hartmann P, Rehwald U, Salzberger B, Franzen C., Sieber M., Wöhrmann A., Diehl V. BEACOPP therapeutic regimen for patients with Hodgkin's disease and HIV infection. Ann Oncol. 2003;14(10):1562-1569.

9. Boue J, Gabarre J, Gisselbrecht G, Reynes J, Cheret A, Bonnet F, Billaud E, Raphael M, Lancar R, Costagliola D. Phase II trial of CHOP plus rituximab in patients with HIV associated non-Hodgkin lymphoma. J Clin Oncol. 2006;24:4123-4128.

10. Dunleavy K, Little RF, Pittaluga S, Grant N, Wayne AS, Carrasquillo JA, Steinberg SM, Yarchoan R, Jaffe ES, Wilson WH. The role of tumor histogenesis, FDG-PET, and shortcourse EPOCH with dose-dense rituximab (SC-EPOCH$\mathrm{RR}$ ) in HIV-associated diffuse large B-cell lymphoma. Blood. 2010;115(15):3017-3024.

11. Xicoy B, Miralles P, Morgades M, Rubio R, Valencia ME, Ribera JM. Long-term follow up of patients with human immunodeficiency virus infection and advanced stage Hodgkin's lymphoma treated with doxorubicin, bleomycin, vinblastine and dacarbazine. Haematologica. 2013;98(8):e85-e86.

12. Little RF, Dunleavy K. Update on the treatment of HIV-associated hematologic malignancies. Hematology. Am Soc Hematol Educ Program. 2013; 2013:382-388.
13. Dunleavy K, Wilson WH. How I treat HIV-associated lymphoma. Blood. 2012;119(14):3245-3255.

14. Uldrick TS, Little RF. How I treat classical Hodgkin lymphoma in patients infected with human immunodeficiency virus. Blood. 2015;125(8):1226-1235.

15. Philip T, Armitage JO, Spitzer G, Chauvin F, Jagannath S, Cahn JY, Colombat P, Goldstone AH, Gorin NC, Flesh $\mathrm{M}$, et al. High-dose therapy and autologous bone marrow transplantation after failure of conventional chemotherapy in adults with intermediate-grade or high-grade non-Hodgkin's lymphoma. N Engl J Med. 1987, 316:1493-1498.

16. Linch DC, Winfield D, Goldstone AH, Moir D, Hancock $\mathrm{B}$, et al. Dose intensification with autologous bone-marrow transplantation in relapsed and resistant Hodgkin's disease: results of a BNLI randomised trial. Lancet.1993;341:1051-1054.

17. Gabarre J, Azar N, Autran B, Katlama C, Leblond V. High-dose therapy and autologous haematopoietic stem-cell transplantation for HIV-1-associated lymphoma. Lancet. 2000;355(9209):1071-1072.

18. Molina A, Krishnan AY, Nademanee A, Zabner R, Sniecinski I, Zaia J, Forman SJ. High dose therapy and autologous stem cell transplantation for human immunodeficiency virus-associated non-Hodgkin lymphoma in the era of highly active antiretroviral therapy. Cancer. 2000;89(3):680-689.

19. Serrano D, Miralles P, Balsalobre P, Díez-Martin JL, Berenguer J. Hematopoietic stem cell transplantation in patients infected with HIV. Curr HIV/AIDS Rep. 2010 7:175. https://doi.org/10.1007/s11904-010-0050-8

20. Krishnan A, Molina A, Zaia J, Smith D, Vasquez D, Kogut N, Falk PM, Rosenthal J, Alvarnas J, Forman SJ. Durable remissions with autologous stem cell transplantation for highrisk HIV-associated lymphomas. Blood 2005;105:874-878.

21. Spitzer TR, Ambinder RF, Lee JY, Kaplan LD, Wachsman W, Straus DJ, Aboulafia DM, Scadden DT. Dose-reduced busulfan, cyclophosphamide, and autologous stem cell transplantation for human immunodeficiency virus-associated lymphoma: AIDS Malignancy Consortium study 020. Biol Blood Marrow Transplant. 2008;14:59-66.

22. Balsalobre P, Diez-Martin JL, Re A, Michieli M, Ribera JM, Canals C, Rosselet A, Conde E, Varela R, Cwynarski K, Gabriel I, Genet P, Guillerm G, Allione B, Ferrant A, Biron P, Espigado I, Serrano D, Sureda A. Autologous stemcell transplantation in patients with HIV-related lymphoma. J Clin Oncol. 2009, 27:2192-2198.

23. Serrano D, Miralles P, Carrion R, et al.: Long term follow-up of autologous stem cell transplant in AIDS related lymphoma patients. Results of Spanish cooperative registry GELTAMO/GESIDA. In 36th Annual Meeting of the European Group for Blood and Marrow Transplantation. Vienna, Austria; 2010. Abstract 822.

24. Re A, Michieli M, Casari S, Allione B, Cattaneo C, Rupolo M, Spina M, Manuele R, Vaccher E, Mazzucato M, Abbruzzese L, Ferremi P, Carosi G, Tirelli U, Rossi G. High-dose therapy and autologous peripheral blood stem cell trans- 
plantation as salvage treatment for AIDS-related lymphoma: long-term results of the Italian Cooperative Group on AIDS and Tumors (GICAT) study with analysis of prognostic factors. Blood. 2009;114:1306-1313.

25. Gabarre J, Marcelin AG, Azar N, et al.: High-dose therapy plus autologous hematopoietic stem cell transplantation for human immunodeficiency virus (HIV)-related lymphoma: results and impact on HIV disease. Haematologica. 2004; 89:1100-1108.

26. Alvarnas JC, Le Rademacher J, Wang Y, Choquet S, Lévy V, Lévy Y, Tubiana R, Charlotte F, Norol F, Calvez V, Spina M, Vernant JP, Autran B, Leblond V. Autologous hematopoietic cell transplantation for HIV-related lymphoma: results of the BMT CTN 0803/AMC 071 trial. Blood. 2016;128(8):10501058.

27. Krishnan A, Palmer JM, Zaia JA, Tsai NC, Alvarnas J, Forman SJ. HIV status does not affect the outcome of autologous stem cell transplantation (ASCT) for non-Hodgkin lymphoma (NHL). Biol Blood Marrow Transplant. 2010;16(9):1302-1308.

28. Diez-Martin JL, Balsalobre P, Re A, Michieli M, Ribera JM, Serrano D, Rossi G, Sureda A (EBMT). Comparable survival between HIV+ and HIV- non-Hodgkin and Hodgkin lymphoma patients undergoing autologous peripheral blood stem cell transplantation. Blood. 2009, 113:6011-6014.

29. Mikhailova NB, Kondakova EV, Vlasov AA, Borzenkova ES, Uspenskaya OS, Osipova NE, Afanasyev BV. Role of hematopoietic stem cell transplantation in treatment of lymphomas. Materialy kongressa gematologov Rossii. Gematologiya i transfuziologiya. 2012; Suppl 3: 15 (In Russian).

30. Cheson BD, Pfistner B, Juweid ME, Gascoyne RD, Specht L, Horning SJ, Coiffier B, Fisher RI, Hagenbeek A, Diehl V. International harmonization project on lymphoma. Revised response criteria for malignant lymphoma. J Clin Oncol. 2007;25(5):579-586.

31. Dunleavy K, Pittaluga S, Shovlin M, Steinberg SM, Cole D, Grant C, Widemann B, Staudt LM, Jaffe ES, Little RF, Wilson WH. Low-intensity therapy in adults with Burkitt's lymphoma. N Engl J Med. 2013;369(20):1915-1925.

32. Nademanee A, O’Donnell MR, Snyder DS, Schmidt GM, Parker PM, Stein AS, Smith EP, Molina A, Stepan DE, Somlo G, et al. High-dose chemotherapy with or without total body irradiation followed by autologous bone marrow and/ or peripheral blood stem cell transplantation for patients with relapsed and refractory Hodgkin's disease: results in 85 patients with analysis of prognostic factors. Blood. 1995;85(5):1381-1390.

33. Afanasyev BV, Popova MO, Bondarenko SN, Zyuzgin I., Babenko EV, Alyanskiy AL, Morsch S, van Lunzen I, Fehse B, Zander AR, Zubarovskaya LS. St. Petersburg experience of allogeneic hematopoietic stem cell transplantation in patients with acute leukemia and human immunodeficiency virus. Cell Ther Transplant; 4(1-2):24-30.

34. Younan P, Kowalski J, Kiem HP. Genetic modification of hematopoietic stem cells as a therapy for HIV/AIDS. Viruses. 2013;5:2946-2962.
35. Mock U., Machowicz R., Hauber I., Horn S, Abramowski P, Berdien B, Hauber J, Fehse B. mRNA transfection of a novel TAL effector nuclease (TALEN) facilitates efficient knockout of HIV co-receptor CCR5. Nucl Acids Res. 2015 DOI: 10.1093/nar/gkv469.

36. Wang CX, Cannon PM. The clinical applications of genome editing in HIV. Blood. 2016;127(21):2546-2552.

37. Popova MO, Sergeev VS, Lepik KV, Shakirova AI, Potter AY, Barkhatov IM, Fehse B, Afanasyev BV. Gene-cell therapy of HIV and hematological malignances based on hematopoietic stem cell transplantation and site-specific genome editing. J Infectology. 2017; 9(1):31-39 (In Russian).

38. Lepik KV, Popova MO, Shakirova, AI, Sergeev VS, Potter AY, Barkhatov IM, Fehse B, Afanasyev BV. Site-specific genome editing for hematopoetic stem cells transplantation-based on gene therapy approaches. Genes and Cells. 2016;11(2):21-29.

39. Popova MO, Lepik KV, Sergeev VS, Shakirova AI, Potter AY, Muslimov AR, Barkhatov IM, Afanasyev BV. Clinical implementation of genome editing for correction of human diseases. Cell Ther Transplant. (2017). 6(1), 37-43. 


\title{
Аутологичная трансплантация гемопоэтических ство- ловых клеток у пациентов с ВИЧ-ассоциированными лимфомами: результаты одноцентрового (CIC725) сравнительного исследования «случай-контроль»
}

\author{
Марина О. Попова, Юлия А. Рогачева, Анастасия В. Некрасова, Иван В. Циганков, Али Базахел, \\ Кирилл В. Лепик, Ольга В. Пирогова, Елена И. Дарская, Лилия В. Стельмах, Юрий Р. Залялов, \\ Иван С. Моисеев, Сергей Н. Бондаренко, Наталья Б. Михайлова, Борис В. Афанасьев \\ НИИ детской онкологии, гематологии и трансплантологии им. Р. М. Горбачевой, Кафедра гематологии, \\ трансфузиологии и трансплантологии, Первый Санкт-Петербургский государственный медицинский университет \\ им. акад. И. П. Павлова (СIC725)
}

\section{Резюме}

Пациенты, инфицированные вирусом иммунодефицита человека (ВИЧ) находятся в группе повышенного риска развития неходжскинских лимфом и лимфомы Ходжкина. При внедрении высокоактивной антиретровирусной терапии (ВААРТ) продемонстрировано, что аутологичная трансплантация стволовых клеток (ауто-ТГСК) является приемлемым, безопасный и эффективным методом лечения пациентов с лимфомами на фоне ВИЧ. Однако количество сравнительных исследований влияния статуса ВИЧ на результаты ауто-ТГСК ограничено. Мы представляем исследование, целью которого является оценить безопасность и эффективность высокодозной химиотерапии с ауто-ТГСК у пациентов с лимфомами на фоне ВИЧ. С января 2016 года выполнены ауто-ТГСК семи пациентам с ВИЧ-ассоциированными лимфомами. Для проведения сравнительного анализа, в исследование включены 28 пациентов с лимфомами без ВИЧ инфекции, которым выполнена ауто-ТГСК в тот же период времени (группа контроля, в соотношении 1:4). Проводилась сравнительная оценка общей 1-годичной выживаемости, восстановления кроветворения, токсично- сти, выживаемости без прогрессирования и кумулятивной частоты рецидивов/прогрессирования в течение одного года после ауто-ТГСК. Общая выживаемость в течение одного года после ауто-ТГСК у пациентов с ВИЧ-ассоциированными лимфомами составила 100\%, выживаемость без прогрессирования - $85,7 \%$, частота рецидивов - $14,3 \%$ и не отличалась от группы сравнения. При анализе токсичности и скорости восстановления кроветворения значимых различий в группах сравнения не обнаружено. Предварительные данные подтверждают, что ВИЧ статус не влияет на результаты ауто-ТГСК для лечения лимфом, и поэтому наличие ВИЧ-инфекции само по себе, не должно влиять на принятие решения о проведении высокодозной химиотерапии с аутологичной трансплантацией гемопоэтических стволовых клеток.

\section{Ключевые слова}

Аутологичная трансплантация гемопоэтических стволовых клеток, ВИЧ, ВИЧ-ассоциированные лимфомы, высокодозная химиотерапия, неходжкинские лимфомы, лимфома Ходжкина, сравнительное исследование «случай-контроль». 